\title{
SEISMIC CONTROL FOR ELEVATED ROADS
}

\section{SEIZMIČKO UPRAVLJANJE IZDIGNUTIM PUTEVIMA - NADVOŽNJACIMA}

Uwe E. DORKA

ORIGINALNI NAUČNI RAD ORIGINAL SCIENTIFIC PAPER

UDK: 625.745 .12 .042

\section{INTRODUCTION}

Especially the 1994 Northridge [1] and 1995 Hanshin-Awaji (Kobe) [2] earthquakes have demonstrated the vulnerability of deck bridges, which make up the bulk of modern bridge construction, especially for elevated road and railroad bridges. Dominant failure modes are: shear failure in piers (Fig. 1) due to horizontal over-loading and drop-off of deck sections due to excessive movements in bearings and piers (Fig. 2).

These failures caused zero functionality of one of the
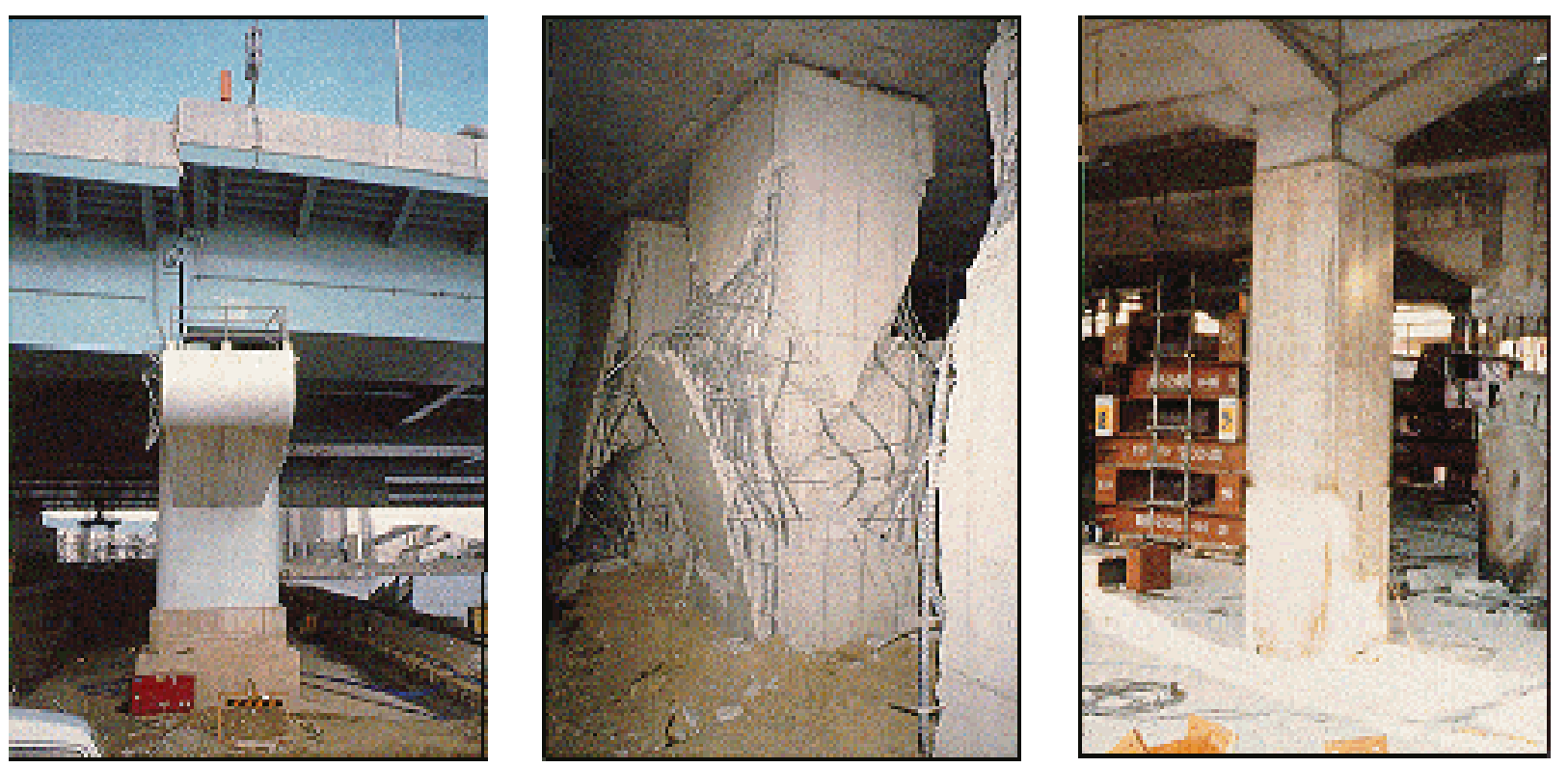

most important infrastructure in this densely populated area for about 1 year! It severely curtailed relief and reconstruction efforts and caused huge direct and longterm economic losses. It is thus obvious, that the piers of elevated roads need special protection from over-loading and foundation failure, since one failed pier (and there are usually hundreds) already renders such a road useless and requires extensive and time-consuming repairs. For the same reason, it is also necessary to prevent drop-off due to bearing failure.

Figure 1. Shear failure of piers of the Hanshin Expressway in Kobe during the Hanshin-Awaji earthquake (from www.fhwa.dot.gov)

Uwe E. Dorka, Professor, Universität Kassel, Kurt-Wolters-

Str. 3, D-34125 Kassel, Germany, +49-561-8042667,

uwe.dorka@uni-kassel.de 


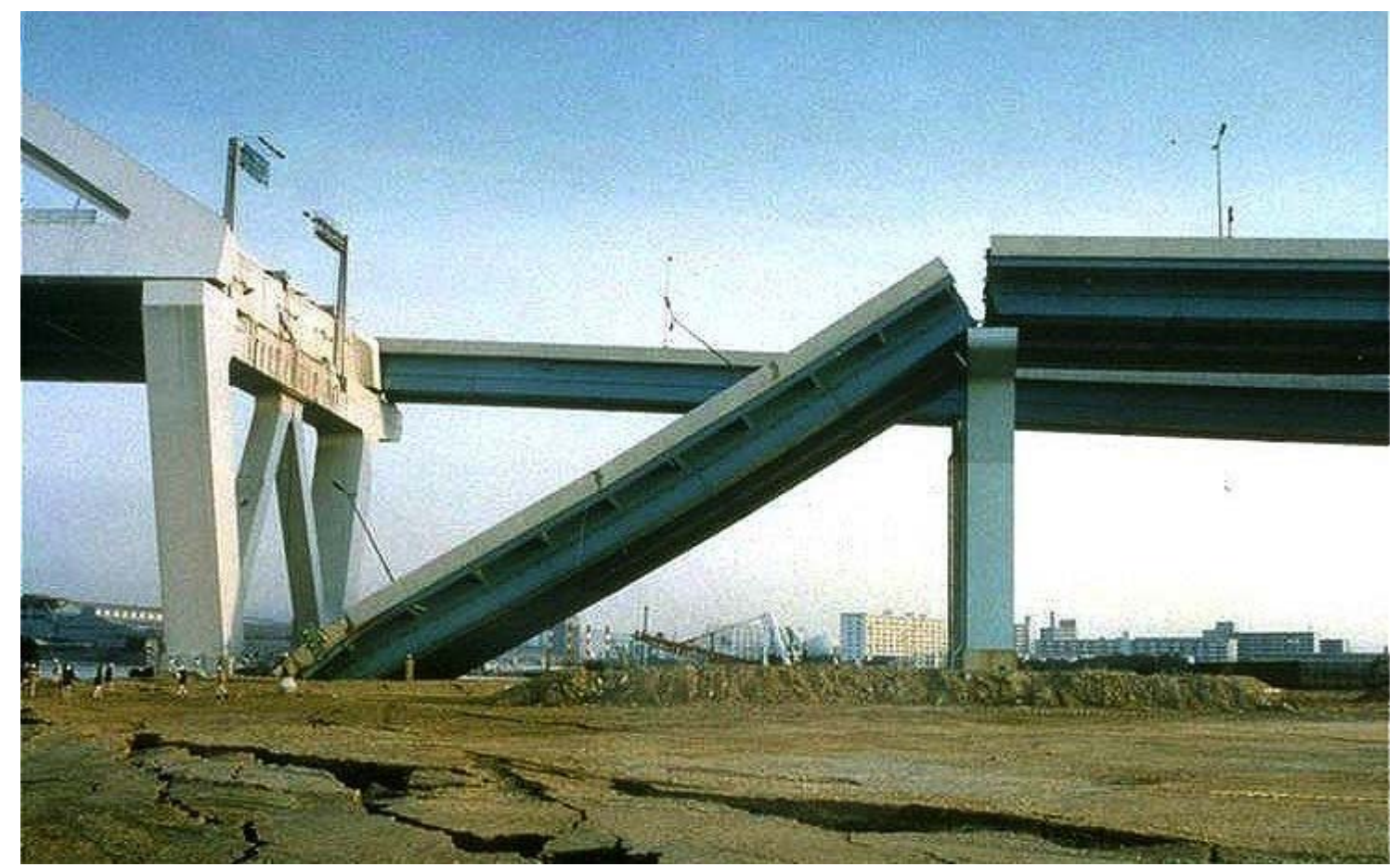

Figure 2. Drop-off of a large steel section of the Hanshin Expressway during the Hanshin-Awaji earthquake (from www.washington.edu)

Conventional deck bridge systems obviously fail to provide such protection, and therefore, the situation has not substantially improved since the Kobe and Northridge events: We need to look into structural systems that provide this required "robustness", in particular by introducing a physical limit to the forces on the piers, and provide enough motion capacity for superstructure even for extreme events that go beyond the design limit, like the Nankai Trough Worst Case Scenario [3], which is now considered for the Osaka highways.

In this context, the tight economic constraints under which such roads are built cannot be forgotten: Their bridges are mainly "mass products". This means that any new structural system should not be more expensive than a conventional deck bridge and furthermore, it should preferably also provide retrofitting solutions for existing deck bridges. Such systems can be conceived through a "Seismic Control" approach.

\section{A BRIEF INTRODUCTION TO "SEISMIC CONTROL"}

There is a lot of misunderstanding even in the academic community about structural control and in particular: "Seismic Control". The definition I use in my work is derived from control engineering: In this context, structural control is

the control of selected response variables of a structure subjected to dynamic loading.
Such variables may be displacements or their time derivatives (velocities, accelerations) and/or forces. Full controllability of a system is of course important, but cannot be achieved under all circumstances. Take a motor for example. It is an assemblage of rigid bodies (pistons, drive shaft etc.). Control over their motions is reduced, if the drive shaft experiences vibrations (e.g. due to a faulty bearing), which eventually will lead to the destruction of the engine. Such "spurious modes" are often a problem in controlled systems. Another example for this is a shaking table.

Besides these rigid body assemblages, vibrational modes also can be controlled. In fact, such control is now almost standard in high-end cars, where the suspension has active (usually hydraulic) components that react to the car's motion and, using highly developed control algorithms, provide an incredibly smooth ride at different speeds and on different road surfaces.

These examples from control engineering show that, full controllability can be achieved in mode control and the control of rigid body mechanisms. For mode control, a structural system is needed that has clearly defined modes. For rigid body control, a structural system must consist of an assemblage of rigid bodies. Their motion can be controlled in connecting links using appropriate devices. For building structures, a number of structural concepts have been identified [6], which allow rigid body motion control (Fig. 3). 

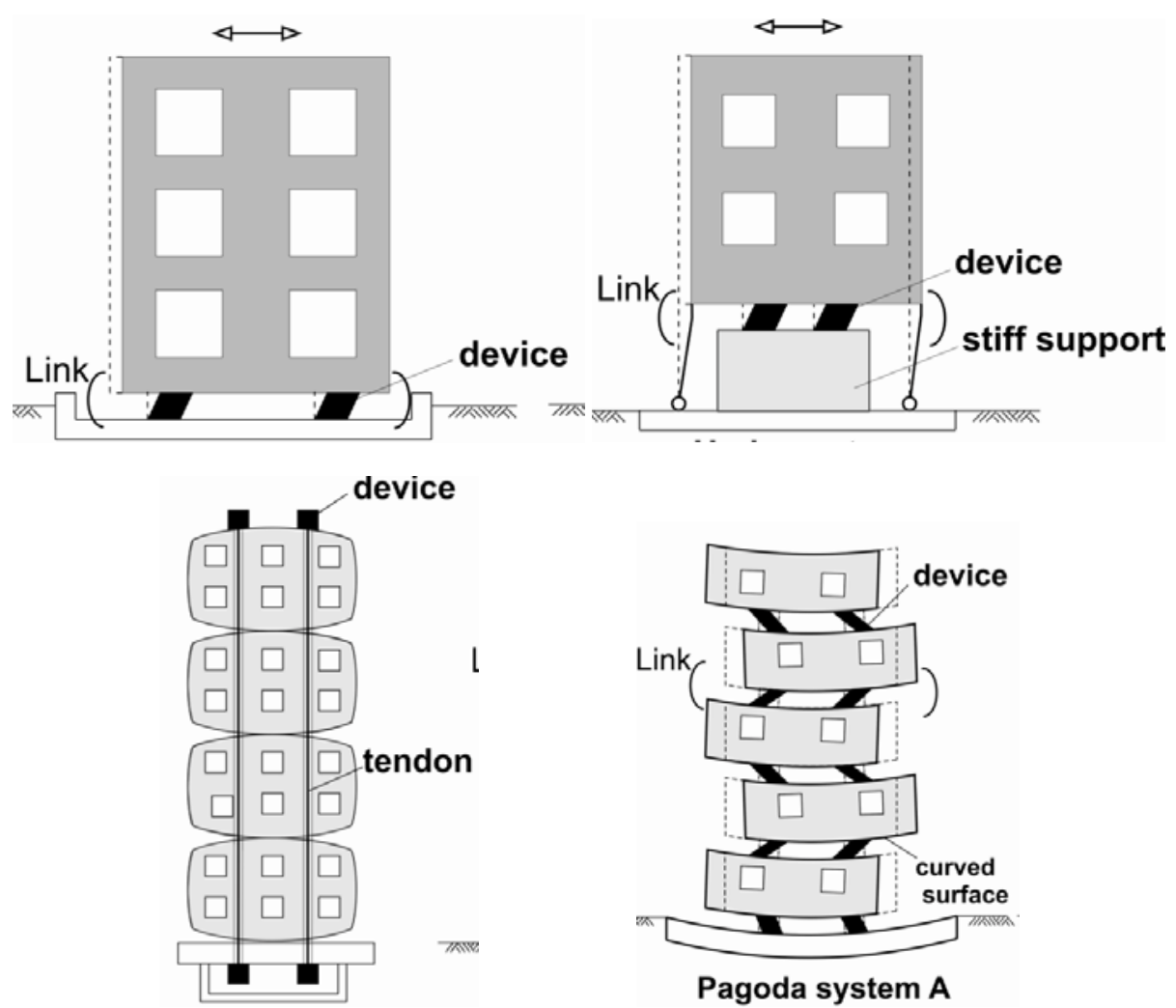

Figure 3. Structural concepts suitable for rigid body motion control and thus Seismic Control (clock-wise from top left): Base Isolation (BI), Hysteretic Device System (HDS, [4,5]), Tendon System (TS) and Pagoda System (PS) (adapted from [6]). HDS applies to deck bridges in particular

The four concepts shown in Fig 3 have been suggested for seismic control [6] because it is rigid body control, which is most suitable under earthquake loading. Rigid body motions avoid dynamic amplification and thus result in small kinetic and potential energies (Fig. 4), which in turn lead to reduced forces and displacements in the structure.

If a seismic control system is able to achieve the behavior given in Fig. 4 (right), the reduction in forces

\section{$\mathrm{E}[\mathrm{KNm}]$}

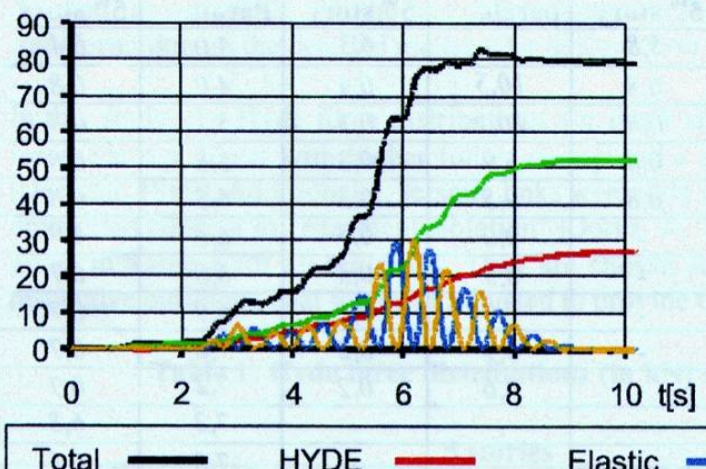

and displacements already make for a much more economical structure. But it is the force-limiting feature in the seismic link of the control system, which provides the required robustness: No matter how strong the earthquake, the forces cannot get bigger than this controlled limit, which protects important structural elements, like piers. And larger motions in the link can usually be accommodated structurally without much difficulty.

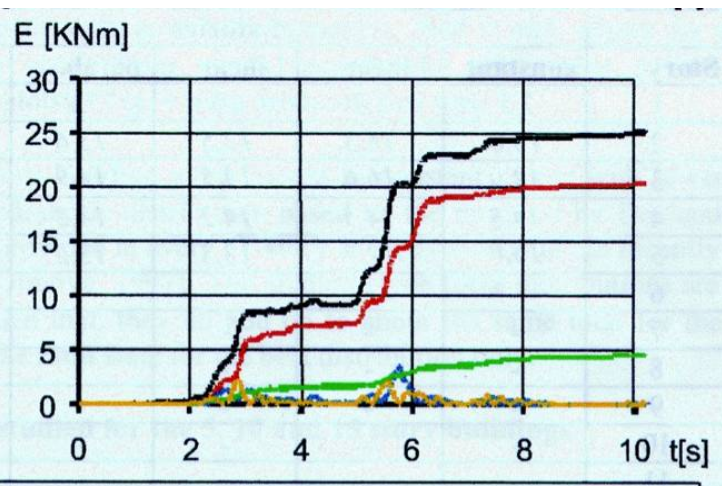

- Viscous Inertial

Figure 4. Typical energies during an earthquake in a conventional structure (left) and in a Seismic Control system (right), HYDE is the (hysteretic) energy dissipated in seismic mitigation devices distributed in conventional structures (added damping, left) or in the seismic link of the control system (right). Note the amplification of potential and kinetic energies in the conventional system, which does not happen under rigid body control. Also note the energy concentration in the link of the control system, where the devices are designed to take care of it. 
In general, control devices used in these systems can be active, passive or semi-active (parameter controlled). With active devices in the links (such as hydraulic jacks), full controllability can be achieved in the systems of Fig 3, but for earthquake loading, the devices and their energy requirements become too large and too costly. Maintenance costs rise over the years for the system just to be ready for a 20 second event. And to make sure that the control system works, back-up must be provided especially for electronic components and sensors.

On the other hand, passive devices like lead-rubber bearings (LRBs) for $\mathrm{BI}$ or elastic-plastic devices like shear panels (SPDs) for HDS can only control force limits. But, since this is the most important aspect for Seismic Control, they are the devices of choice (Fig. 5).

The SPD in Fig. 5 (right) is a specimen used in pseudo-dynamic simulations of a half-scale 3-storey structure at the Joint Research Centre (JRC) of the European Union in Ispra, Italy, to provide proof-ofconcept for the HDS. The HDS was created from a pure steel-frame, which had undergone previous extensive seismic testing and thus sustained some damage. It was converted into an HDS (Fig. 6) by bracing the upper storeys (to make them a rigid body) and providing the required link in the ground floor with the SPD of Fig. 5 as control device.

This HDS was subjected to a series of severe earthquakes. It proved the HDS concept by confirming the desired development of energies according to Fig. 4, which resulted in small displacements and forces even under extreme events. It also confirmed the robustness of the SPD, which, during 50 simulations, developed some elastic-plastic buckling and minor cracks (Fig. 5, right), but retained a yield force of $92 \%$ and a full hysteretic loop (Fig. 6, right).

Semi-active devices like magneto-rheological devices or friction devices like the UHYDE-fbr (Fig. 7), which have been designed for bridge applications, can change their parameters according to the response of the structure and a control algorithm. Adjusting their parameters requires very little energy, but can improve controllability in comparison to passive devices and thus the response of the structure. They may also be used in controlling the response under other dynamic loading, such as wind and traffic, which may provide for future applications in cable bridges [7].
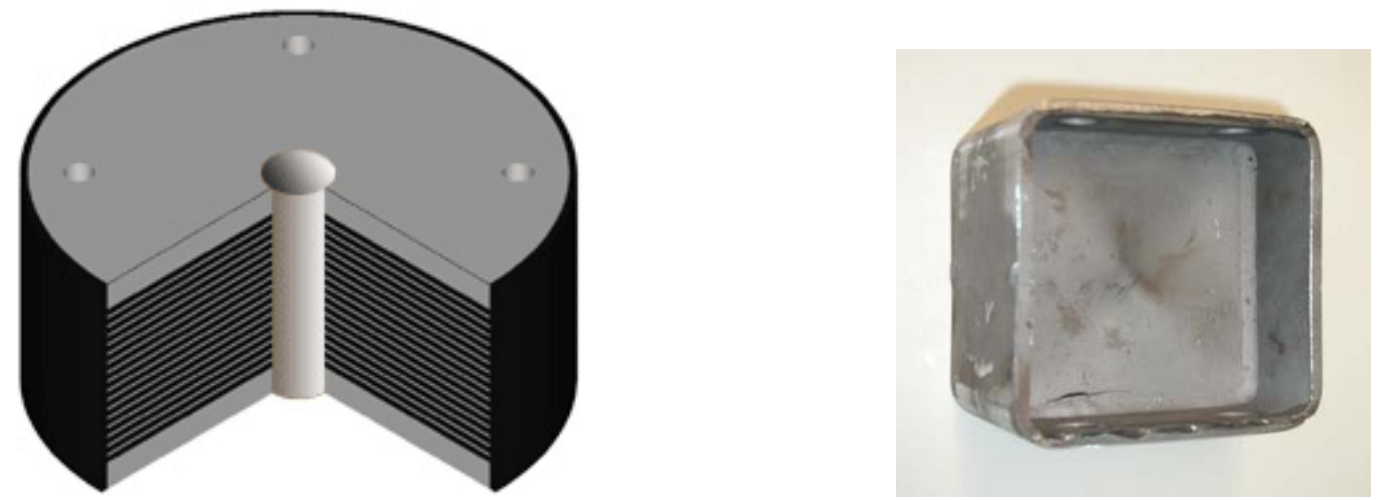

Figure 5. Lead-rubber bearings (LRBs, left) and Shear Panels made of mild steel (SPDs, right, specimen after pseudodynamic testing at the JRC Ispra) are usually the devices of choice for BI and HDS systems, respectively
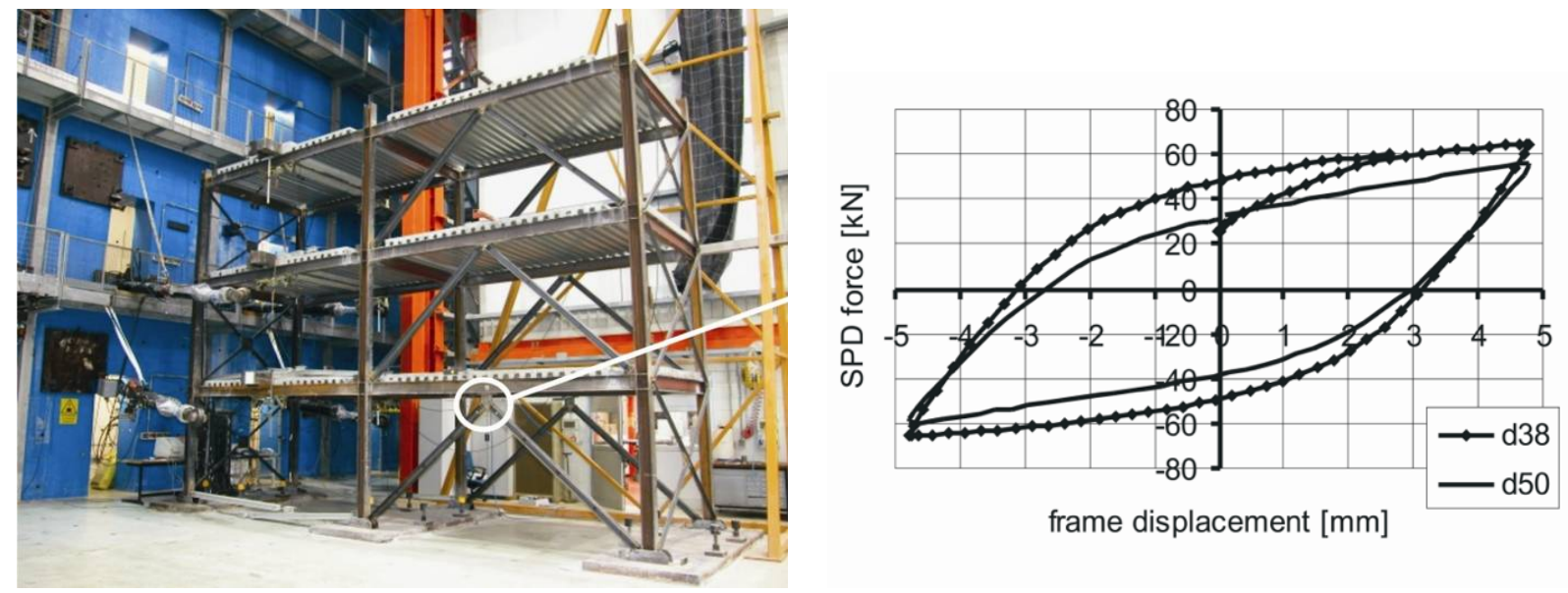

Figure 6. Half-scale steel frame at the JRC Ispra converted into a HDS by bracing the upper floors and providing a SPD as passive control device in the ground floor (white circle); and hysteresis loop of the SPD after 50 severe pseudodynamic earthquake simulations 

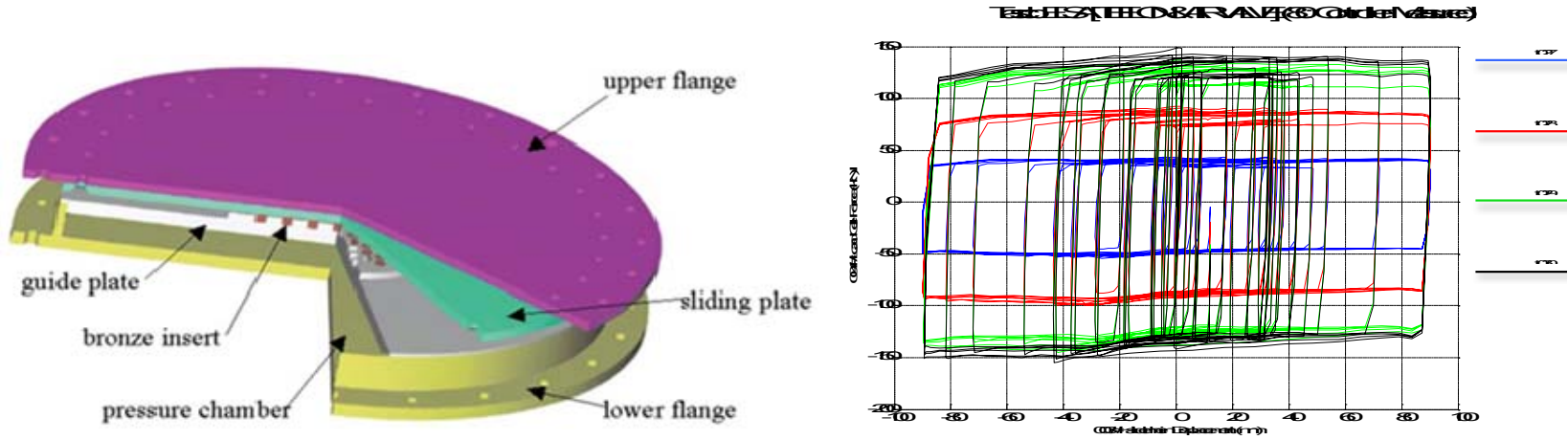

Figure 7. Bi-directional semi-active friction device UHYDE-fbr (US Patent No 546047) designed for bridge applications. Friction between the bronze inserts and sliding plate is controlled by air pressure. The specially designed bronze inserts provide very stable and repeatable behaviour under varying pressure levels (hysteresis loops during repeated testing with constant air pressure at the JRC Ispra, right)

It must be noted here that, distributing seismic mitigation devices in some manner throughout a conventional structure (Fig. 8) is NOT "Seismic Control" as defined here: These devices are unable to control any response variable. They provide an overall response reduction, but with a limited energy dissipation capacity (see Fig 4 left) and an additional price tag, since a large number of expensive devices are usually needed. There is no comparable benefit in robustness and economy when comparing such "added-damping" or addeddamping-and-stiffness" systems to genuine Seismic Control [8].

\section{SUITABLE "PASSIVE CONTROL" FOR DECK BRIDGES: THE ISU-BRIDGE TESTS}

Deck bridges already have a natural affinity to Seismic Control: Often, they already provide rigid bodies (the deck and the piers) connected with a link where one usually finds conventional bearings. To use this link as "seismic link" to control the rigid body motion with appropriate devices is almost self-evident. Looking at the seismic control concepts in Fig. 3, it appears that typical deck bridges lend themselves easily to an adoption of the HDS concept (Fig 9). This will provide the required control of the force limit, thus protecting the piers from over-loading, and by virtue of rigid body control, provide small link displacements. In many existing cases, the links are even sufficient for an easy retrofit.

Because most researchers and practicing engineers only have knowledge of $\mathrm{BI}$, they tend to confuse $\mathrm{BI}$ with HDS, although $\mathrm{BI}$ is located at the base of a structure and the desired "isolation" is typically achieved with soft devices. HDS on the other hand has a link within the structure and therefore cannot "isolate" it from the ground motion, but it can control the forces in that link (and thus in the structure), which for this reason needs to be stiff with yielding or friction devices providing a physical force limit [9].

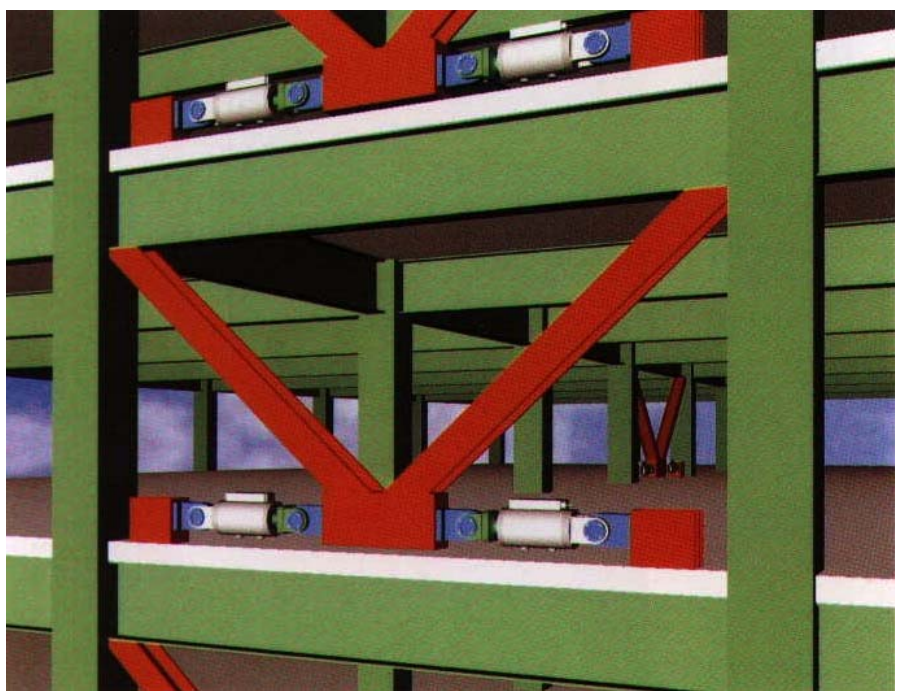

Figure 8. Distributing seismic mitigation devices, such as hydraulic dampers or even elastic-plastic or friction devices throughout a conventional structure without changing it into a genuine seismic control concept does not provide any controllability. Such "added-damping" or added-damping-and-stiffness" concepts are not "Seismic Control". 


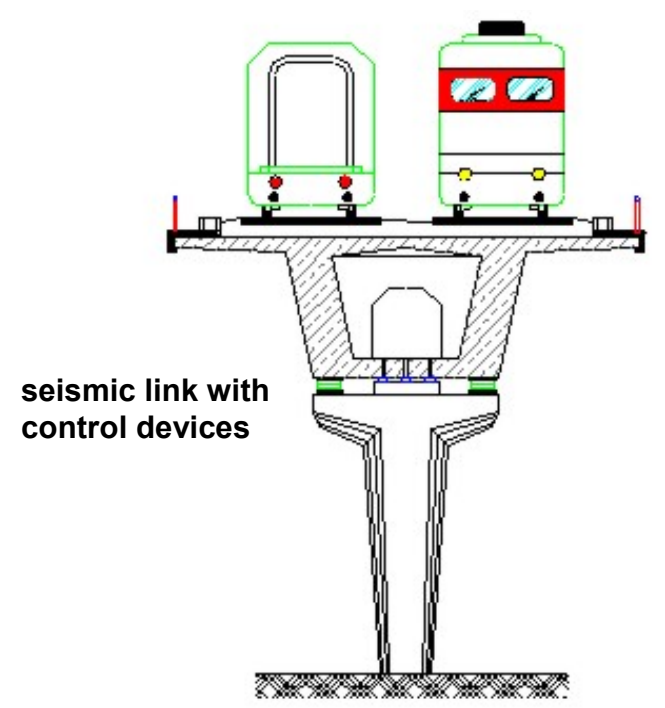

Figure 9. Seismic control of deck bridges using the (often existing) link between deck and piers. This automatically leads to an HDS-type concept (Fig. 3), but devices typical for the BI concept (e.g. LRBs) have been used, like in the reconstructed Hanshin Expressway in

$$
\text { Kobe }
$$

Not only because of the confusion between $\mathrm{BI}$ and HDS, but also because of the easy and cheap availability of soft Bl-type devices (like LRBs), devices designed for $\mathrm{BI}$ have been used also in HDS-type deck bridge structures, in one case even replacing elasticplastic devices that actually did protect a deck bridge during the 1999 Kocaeli and Düze earthquakes: The Bolu viaduct was subjected to excessive displacements since the fault rupture ran right through it (Fig. 10) $[10,11]$.

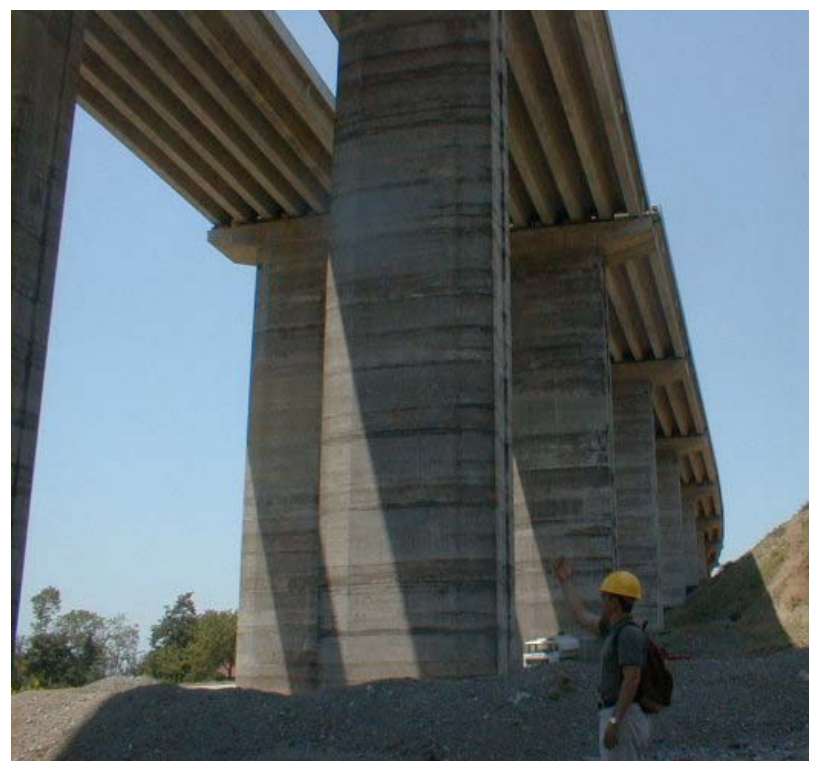

Figure 10. Bolu viaduct with large permanent offset due to fault rupture (from www.purdue.edu)

This was not considered in the initial design, so the elastic plastic devices over-extended (Fig. 11), but the bridge did not collapse! This makes the Bolu viaduct the first real-life proof of the robustness of the HDS concept for deck bridges. Because of the before mentioned confusion among the experts, this observation went largely unnoticed

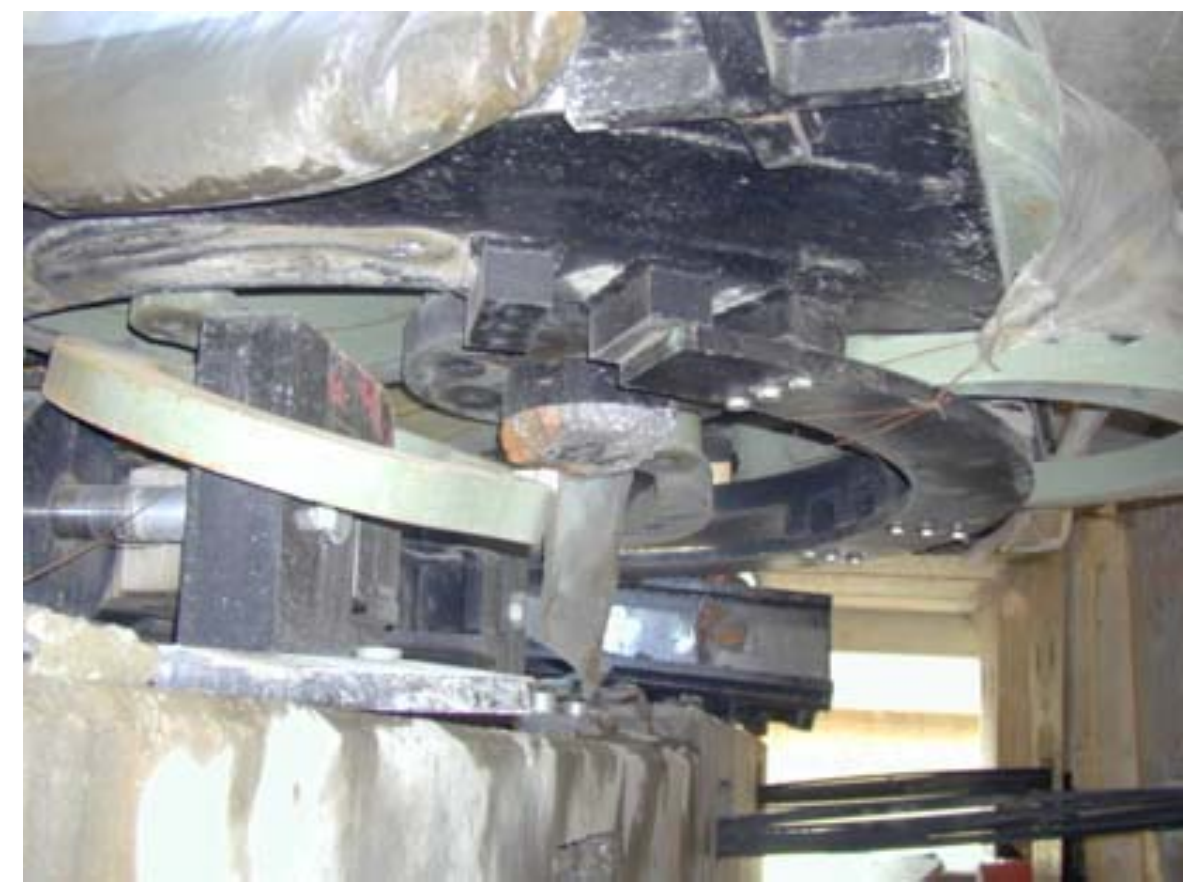

Figure 11. Over-extended "moon shaped" elastic plastic device in the Bolu viaduct [11] due to permanent fault line displacement. These devices were replaced by LRBS 
One of the goals of the NATO Science-for-Peace project "Seismic Upgrading of Bridges in South-East Europe by Innovative Technologies" (NATO-SfP project ISUbridge) was therefore to study the effectiveness of passive control concepts for seismic upgrading of regular deck bridges, in particular the HDS concept. In addition to the question, which kind of device is most suitable, the robustness of such a passive seismic control system was studied when it is subjected to unexpectedly large ground motions. A recent study on a steel-concrete composite frame retrofit using the HDS concept [12] showed for example that, the limit force in the link is the controlling factor for the resulting displacements and not the dissipation, which is the usual line of thought. Also, an older comparison of a deck bridge using LRBs vs. stiff-ductile devices indicated a superior performance of the latter [13].

To investigate these issues, a 3-span model of a deck bridge was constructed within ISUbridge, which allows the placement of various devices between piers and deck and abutments and deck (Fig. 12). This model was placed diagonally on the large shaking table at IZIIS, Skopje, to induce a bi-directional ground motion when operating the table in its horizontal direction.

In order to study the effect of different devices on the response of the model under various base excitations, two controllable friction devices UHYDE-fbr (Fig. 7) were placed between deck and piers in parallel to elastomeric bearings (Fig. 13).

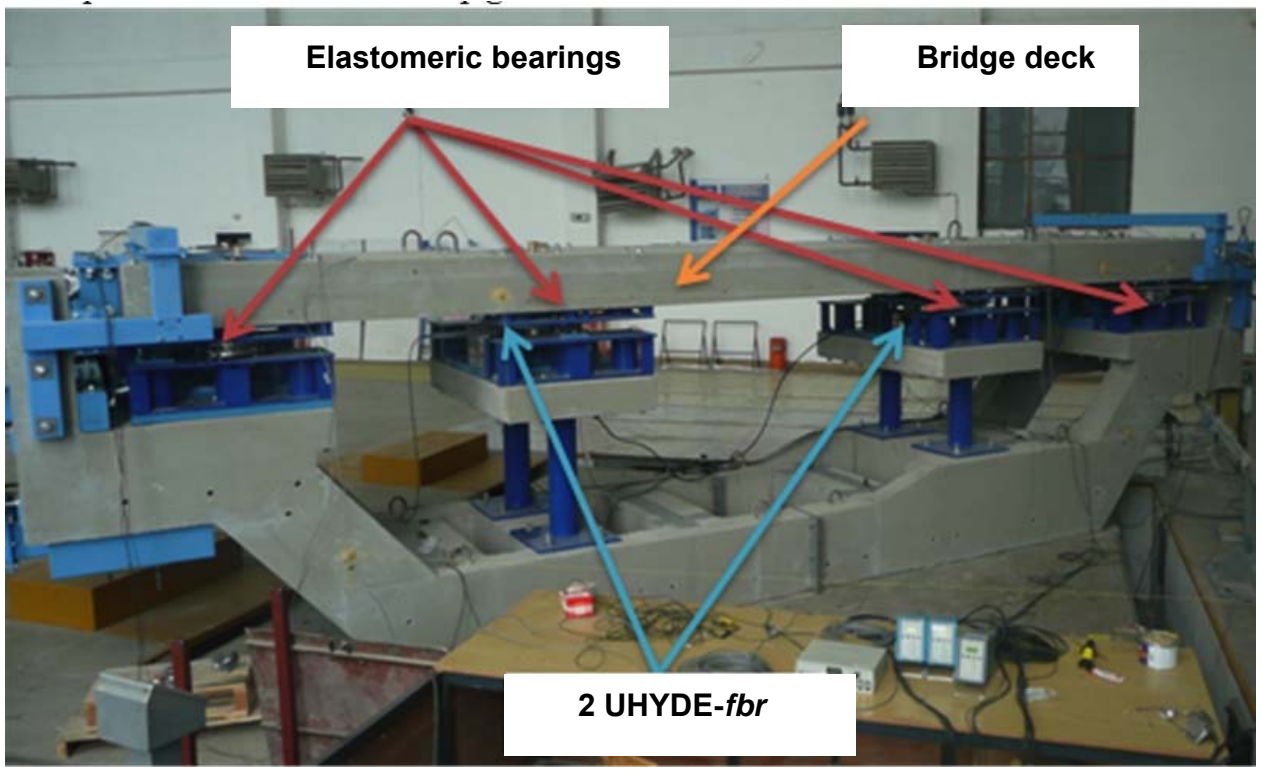

Figure 12. Three-span deck bridge model placed diagonally on the shaking table at IZIIS with the possibility to introduce seismic mitigation devices between deck and piers or deck and abutments in the manner of the HDS Seismic Control concept

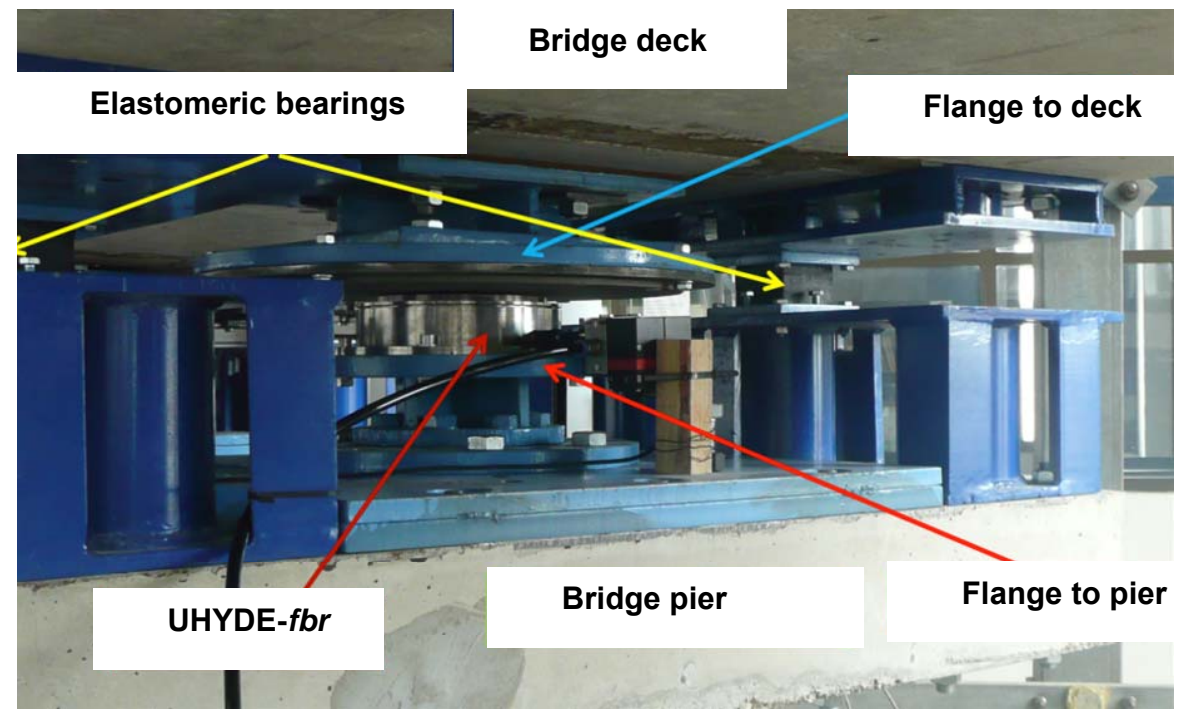

Figure 13. Placement of a UHYDE-fbr between pier and deck of the model bridge (via two flanges) in parallel to elastomeric bearings 
The pressure control of the two UHYDE-fbrs required for the simulation of the behaviour of different passive devices, like LRBs (bi-linear hysteresis loop, Fig. 14 top) or viscous dampers (elliptic hysteresis loops, Fig 14 bottom), etc. was developed and tested at Universität
Kassel (UNIKA) using sine-sweep excitations (constant and variable frequency and amplitude). Figure 14 exemplifies the excellent response of the UHYDE-fbr in the pressure tests at UNIKA.
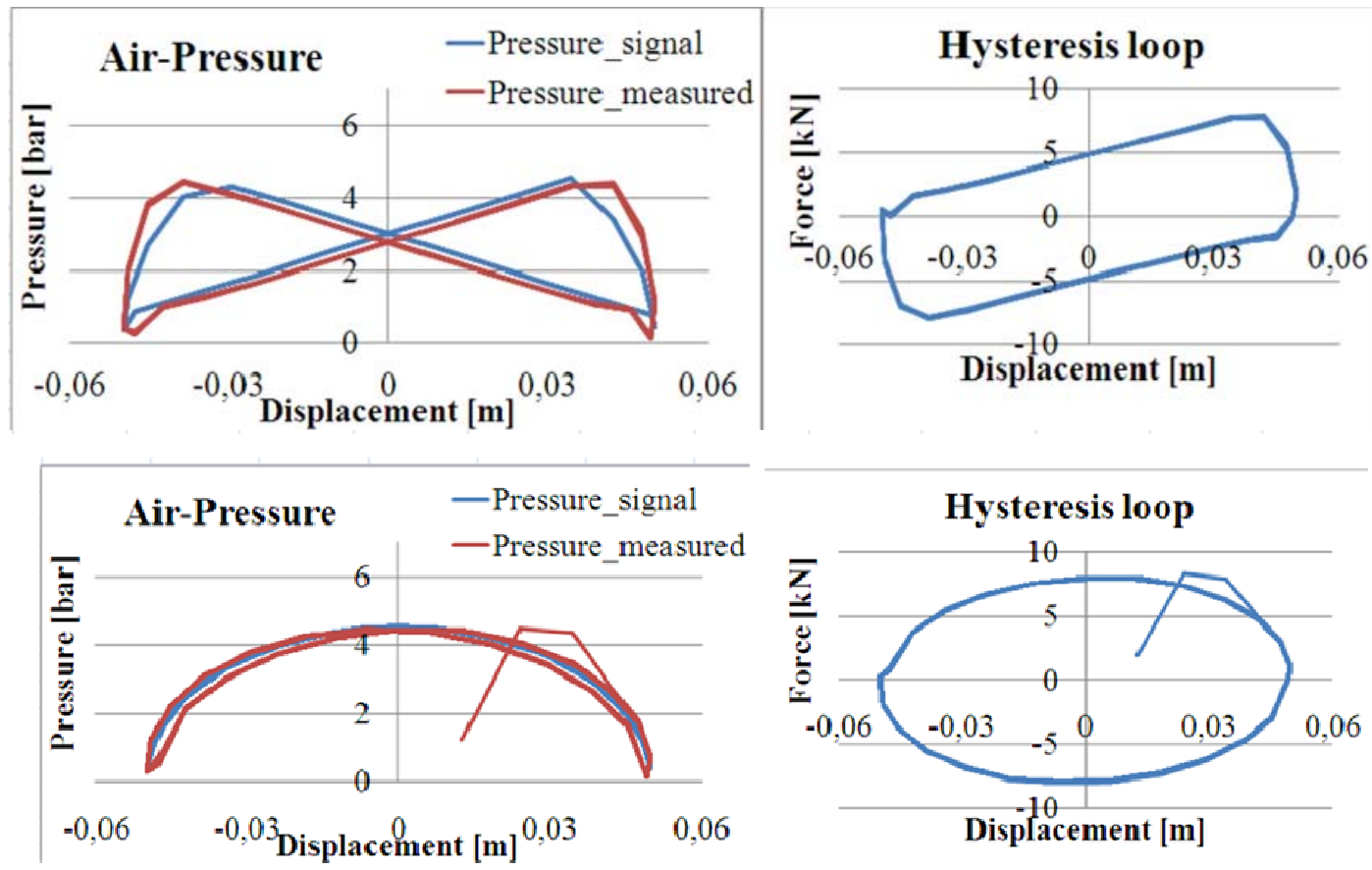

Figure 14. Examples of UHYDE-fbr air pressure control and resulting hysteresis loops: Top: bi-linear loop with post-yield stiffness representing an LRB. Bottom: velocity dependent loop representing a viscous damper. Test frequency: $2 \mathrm{~Hz}$

Table 1. Testing program with various hystereses generated by the UHYDE-fbrs. Each test no. represents several runs with increasing excitation

\begin{tabular}{|c|c|c|c|c|}
\hline \multirow[b]{2}{*}{$\begin{array}{l}\text { Simulated device } \\
\text { behaviour }\end{array}$} & \multirow[b]{2}{*}{$\begin{array}{l}\text { Pressure control, } \\
\text { UHYDE-fbr [bar] }\end{array}$} & \multicolumn{3}{|c|}{ Test No. } \\
\hline & & $\begin{array}{c}\text { El- } \\
\text { Centro }\end{array}$ & $\begin{array}{l}\text { Ulcinj- } \\
\text { Albatros }\end{array}$ & $\begin{array}{l}\text { Sine- } \\
\text { sweep }\end{array}$ \\
\hline \multirow{4}{*}{$\begin{array}{ll}\text { Stiff-plastic, } & \text { different } \\
\text { yield levels } & \end{array}$} & 0.0 & 1 & 14 & 27 \\
\hline & 1.0 & 2 & 15 & 28 \\
\hline & 3.0 & 3 & 16 & 29 \\
\hline & 6.0 & 4 & 17 & 30 \\
\hline \multirow{2}{*}{$\begin{array}{l}\text { Bi-linear, negative post } \\
\text { yield stiffness }\end{array}$} & $3.0-150^{*} d$ & 5 & 18 & 31 \\
\hline & $3.0-300^{*} d$ & 6 & 19 & 32 \\
\hline \multirow{2}{*}{$\begin{array}{l}\text { Bi-linear, positive post } \\
\text { yield stiffness }\end{array}$} & $3.0+150 * d$ & 7 & 20 & 33 \\
\hline & $3.0+300^{*} \mathrm{~d}$ & 8 & 21 & 34 \\
\hline \multirow{2}{*}{$\begin{array}{ll}\text { Viscous } & \text { (velocity } \\
\text { dependent) } & \end{array}$} & $0.0+30 * v$ & 9 & 22 & 35 \\
\hline & $0.0+60^{*} v$ & 10 & 23 & 36 \\
\hline \multirow[t]{2}{*}{ Acceleration dependent } & $3.0+1.5^{\star} a$ & 11 & 24 & 37 \\
\hline & $3.0+3.0^{\star} a$ & 12 & 25 & 38 \\
\hline \multirow{3}{*}{$\begin{array}{l}\text { Elastic-plastic device } \\
\text { failure }\end{array}$} & $P=6.0,|d|<2 \mathrm{~mm}$ & \multirow{3}{*}{13} & \multirow{3}{*}{26} & \multirow{3}{*}{39} \\
\hline & $P=3.0,|d|<5 \mathrm{~mm}$ & & & \\
\hline & $P=1.0,|d|>5 \mathrm{~mm}$ & & & \\
\hline
\end{tabular}


Table 1 summarizes the testing program for the shaking table tests on the model bridge at IZIIS. Each color represents a different type of simulated device. Blue stands for stiff-ductile force limiting devices, such as friction or yielding devices. Green stands for bi-linear devices, with bi-linear positive post-yield stiffness representing devices used in Base Isolation, like LRBs. Orange is for viscous dampers and brown for the simulation of a failure in a stiff-ductile device after exceeding its design limit. Yellow is for acceleration dependent devices, which have not been invented yet, but the UHYDE-fbrs have no trouble simulating this.

The model bridge was subjected to a sine-sweep excitation as well as to the records from the UlcinjAlbatros and EL-Centro earthquakes for each simulated device. Each test started small with increasing excitation for the following repeated runs. Thus, approximately 150 test runs were performed including large excitations. The performance of the UHYDE-fbrs was such that, not even the bronze inserts needed exchanging.

Figure 15 compares the results of tests no. 16 (stiffplastic, 3.0 bar) and 26 (simulating device failure by dropping successively from 6.0 to 1.0 bar) in the time and frequency domains. A premature device failure is simulated here: Initial failure starts already at 7 seconds into the test, where the intensity of the ground motion is roughly at $30 \%$. Comparing the dotted red lines (failed device) with the solid black one (intact device) shows an increase in displacements of the deck, which is expected, but stays well below danger level, when the deck would destroy the elastomeric bearings and would be in danger of slipping off the piers. This demonstrates the robustness of the HDS concept for deck bridges.

Figure 16 compares the maximum response of the deck (displacement and acceleration) for all simulated devices including device failure for all excitations (sine sweep and the two earthquake records). The same colour coding is used for the bars as in Table 1 to provide easy comparison. A clear trend independent of the excitation is visible with the most favourable performance provided by stiff-plastic (friction or yielding) devices, which allow adjustments of displacements and accelerations almost to any desired level.

The response of the model bridge allows for the following observations:

- With constant pressure (stiff-plastic devices), forces in the piers are under control and constant, thus effectively protecting the piers from over-load.

- In this case, the higher the pressure in the UHYDE-fbr, the lower the deck displacements and acceleration, both of which can be adjusted to almost any desired level. But forces increase, especially in the piers.

- Stiff-plastic control devices provide the best performance (friction or stiff yielding devices) followed by acceleration dependent (how to construct these is an open question, unless semi-active devices are used) and bi-linear devices (base isolation devices like LRBs). This confirms earlier numerical studies mentioned above [13].
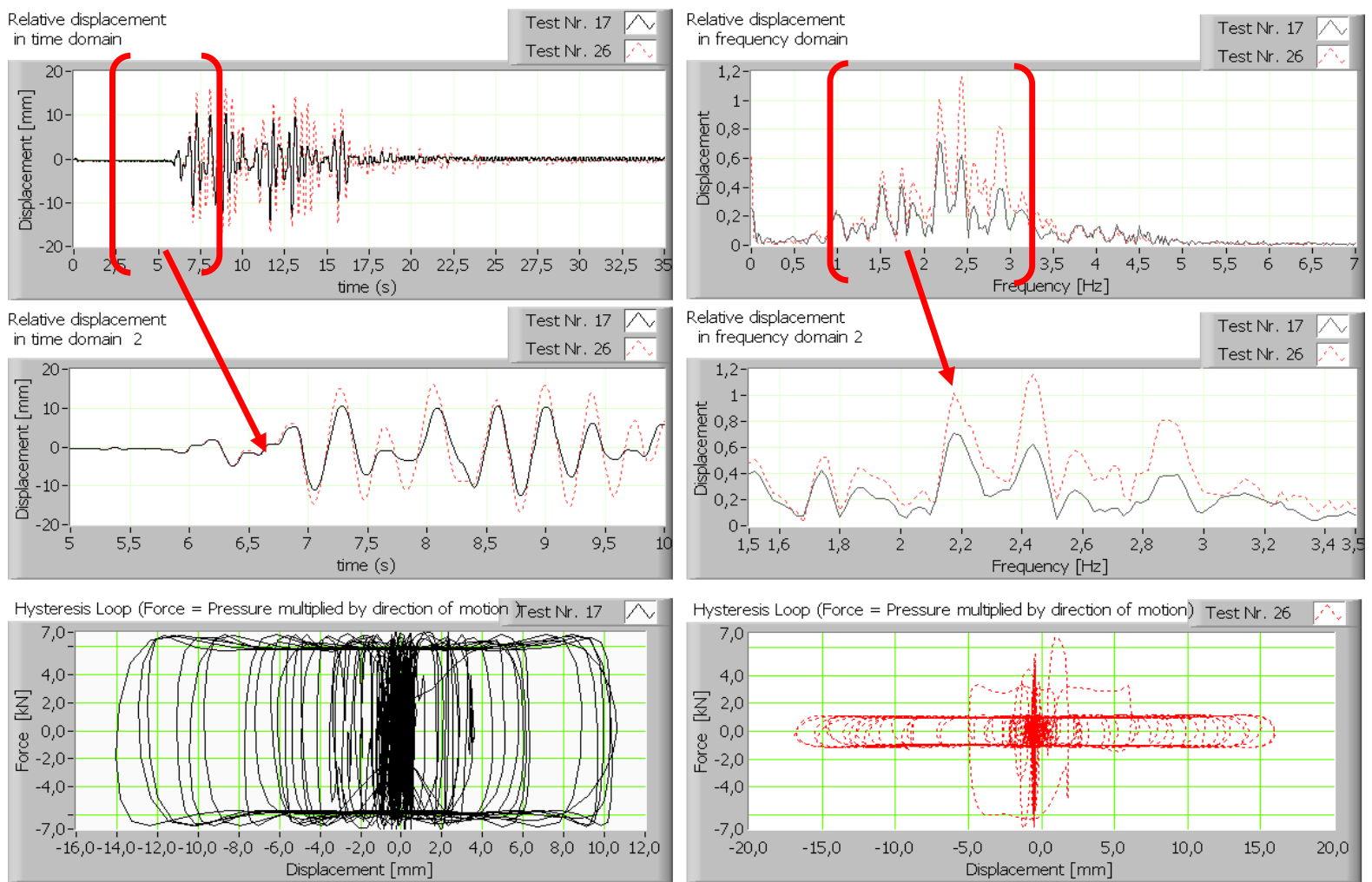

Figure 15. Comparison between constant pressure (solid line) and drop in pressure (dashed line). $1^{\text {st }}$ row: deck displacement in the time and frequency domains. $2^{\text {nd }}$ row: enlarged strong motion phase. $3^{\text {rd }}$ row: Hysteresis generated by UHYDE-fbr devices during the shaking table tests. 

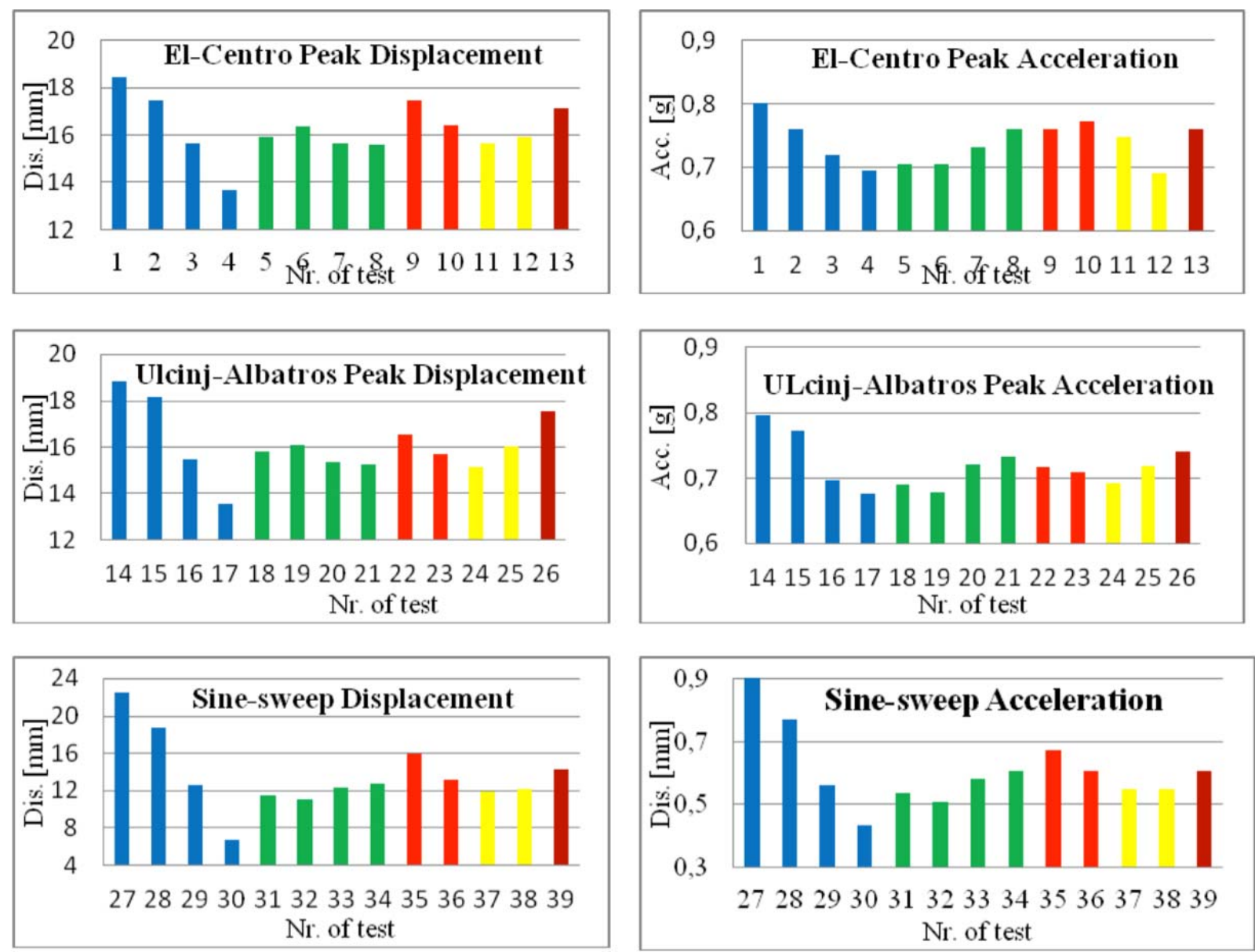

Figure 16. Maximum response of the model bridge under El-Centro, Ulcinj-Albatros and sine-sweep for various simulated passive devices: Blue: stiff-plastic. Green: bi-linear (LRBs). Red: viscous damper. Yellow: depending on acceleration. Brown: stiff-plastic device failure. Nr. of test refers to Table 1.

- Viscous dampers are favored today but do not perform well in comparison with stiff-plastic devices or even base isolation devices when used in deck bridges!

- The simulation of premature failure of stiff-plastic devices (sudden drop in pressure in UHYDE-fbrs) showed the expected increase in deck displacements (Fig. 15), which was not suficient to cause substancial damage to the bridge. Forces on the piers naturally dropped, thus pier protection remained intact! This demonstrates the robustness of the HDS concept for deck bridges and corroborates the observations at the Bolu viaduct.

\section{CONCLUSIONS}

Common failures of deck bridges during earthquakes, like shear failure of columns and drop-off of girders should be avoided in the future even under extreme events not considered in the design since these "mass produced" bridges are the backbone of all elevated roads in mayor urban areas in this world. Conventional structural concepts are failing to provide this requirement for robustness.
Seismic Control (as opposed to added-damping or added-damping-and-stiffness) provides robust and economic solutions through the control of rigid body motions. Among the four basic structural concepts utillizing rigid body control, the Hysteretic Device System (HDS) is most suitable for deck bridges. It is easily implemented into such bridges, even into existing ones, since the required "seismic link" is already there and stocky piers together with horizontally rigid decks provide the easily controllable rigid body motion required by this concept.

A testing campaign on the IZIIS shaking table in Skopje using a model bridge within the SfP-project ISUbridge allowed the simulation of various passive devices in these links using the semi-active patented friction device UHYDE-fbr. The best performance and robustness was provided by stiff-plastic devices, which corroborated earlier numerical studies.

This also indicates that the elastic-plastic devices that „failed“ in the deck bridge in Bolu, Turkey under excessive displacements beyond their design limit most likely safed this bridge, which follwed the HDS concept.

Because most experts do not differentiate between the $\mathrm{BI}$ and HDS concepts, soft $\mathrm{BI}$ devices are typically used today in deck bridges that are natural HDSs, which unfortunately reduces their performance and robustness. 


\section{ACKNOWLEDGEMENTS}

This work was supported in part through the NATO Science for Peace program under the project ISUbridge (SfP grant no. 983828). Mr. Nasser Khanlou performed the experiments at IZIIS and processed the data. These tests would not have been possible without IZIIS's excellent lab team. These contributions are gratefully acknowledged.

\section{REFERENCES}

[1] Hall, J.F. (Editor), Northridge Earthquake of January 17, 1994 reconnasisance report, Earthquake Spectra, supplement to Vol. 11, 1995

[2] Comartin, C.D., Greene M., Tubbesing, S.K., The Hyogo-Ken Nanbu Earthquake, Great Hanshin Earthquake Disaster January 17, 1995, Preliminary Reconnasisance Report, EERI publication no. 9504, 1995

[3] Japan Cabinet Office, Nankai Trough Earthquake Damage Information. Available from: http://www.bousai.go.jp/jishin/nankai/nankaitrough_ info.html, 2013

[4] Dorka, U.E., Hysteretic device systems for earthquake protection of buildings, Proc. 5th US Conf. Earthquake Engineering, Chicago, USA, 775785, 1994

[5] Dorka, U.E., Bayer, V., Distribution of seismic links in Hysteretic Device Systems, Proc. 12 ${ }^{\text {th }}$ World Conf. Earthquake Engineering, Auckland, New Zealand, 2000

[6] Dorka,U.E., Erdbebensicherung durch Structural Control, Stahlbau Vol. 73, Heft 9, 2004

[7] Abdel Raheem, S.E., Dorka, U.E., Hayashikawa, T., Friction based semi-active control of cablestayed bridges. Journal of Structural Engineering Vol. 53A, 428-438, 2007
[8] Schmidt, K., Dorka, U.E, Comparative studies of steel frame retrofitted with HYDE System and Added Damping System subjected to Near-Field Earthquakes, Proc. SE-40EE, Skopje, Mazedonien, 2003

[9] Schmidt, K., Dorka U.E, Experimental verification of HYDE-System, Proc. 13th WCEE, paper No. 3163, 2004

[10] Imbsen, R.A., Roblee, C.J., Yashinski, M., Berilgen, M.M., Toprak, S., Impact on highway structures, Chapter 17, 1999 Kocaeli, Turkey earthquake reconnaissance report, Earthquake Spectra supplement to Vol. 16, 2000

[11] Hamid, G., Bolu Viaduct: damage assessment and retrofit strategy, Federal Highway Administration, Turner-Fairbank Highway Research Center, Georgetown

[12] Dorka, U.E., Khanlou, N., Self-centering Hyde System for seismic retrofit of composite frames, Proc. Composite Construction VII, Palm Cove, Australia (2013, publication pending).

[13] Dorka, U.E., Flygare, E. Ji, A., Passive seismic control of bridges by Hysteretic Device Systems, $2^{\text {nd }}$ World Conf. Structural Control, Kyoto, Japan, 1998 


\section{SEISMIC CONTROL FOR ELEVATED ROADS}

\section{Uwe E. DORKA}

Past earthquakes have demonstrated the vulnerability of deck bridges, which are the most common type in elevated roads. Especially over-loading of piers and drop-off of sections are a continuing concern. Seismic Control concepts, when correctly understood and applied, can provide the necessary physical force limits and reduced displacements even under loading beyond the design limit. The concept of choice here is the Hysteretic Device System since deck bridges usually provide a natural seismic link between piers and deck. To study the performance and robustness of this concept, shaking table tests were performed at IZIIS, Skopje during the NATO-SfP project ISUbridge on a model deck bridge using controllable friction devices UHYDE-fbr to simulate the behavior of different passive devices including device failure. The tests showed that a stiff-ductile device in the link not only protects the piers from over-load, but also provides superior performance compared to viscous or soft base-isolation devices. Failure of such a device further reduced the demand on the piers but did not lead to excessive deck displacements or damage, thus confirming considerable seismic robustness for the HDS concept. This corroborates observations on the Bolu viaduct during the Kocaeli event. Unfortunately, HDS is often confused with BaseIsolation, which leads to the application of Bl-devices, like LRBs and thus a reduction in performance and robustness. This is even more true for viscous devices, which are favored today.

Key words: seismic control, passive control devices, UHYDE-fbr, deck bridges, elevated roads, shaking table tests, Hyde System, seismic robustness.

\section{SEIZMIČKO UPRAVLJANJE IZDIGNUTIM PUTEVIMA - NADVOŽNJACIMA}

Uwe E. DORKA

Zemljotresi iz prošlosti ukazali su na osetljivost kolovozne table mostova, koji predstavljaju i najčešći tip izdignutih puteva. Naročitu brigu predstavlja preopterećenje stubova i opadanje nosivosti preseka. Koncepti seizmičke zaštite, kada se korektno rezumeju na pravi način i primenjuju, mogu da obezbede neophodnu nosivosti i smanjena pomeranja čak i u slučaju opterećenja koje prevazilazi projektovanu nosivost. Izabrani koncept u ovom slučaju je Hysteretic Device System (HDS), tj. sistem histerezisnih uređaja, dok kolovozna tabla obično obezbeđuje prirodnu seizmičku vezu između nje i stuba. U cilju istraživanja performansi i robustnosti ovog koncepta, izveden je test na vibroplatformi u IZIIS-u, u Skoplju, u okviru NATOSfP projekta ISUbridge na modelu kolovozne table (rasponske konstrukcije) mosta pri čemu su korišćeni uređaji na bazi trenja UHYDE-fbr da bi se simuliralo ponašanje različitih pasivnih uređaja uključujući i otkaz uređaja. Testovi su pokazali da krut-duktilan uređaj na mestu spoja ne samo da štiti stub od preopterećenja, već i obezbeđuje mnogo bolje ponašanje u poređenju sa viskoznim uređajima ili onim baziranim na mekoj izolaciji. Otkaz takvog uređaja smanjio je zahteve nosivosti stubova ali nije doveo do povećanja pomeranja ili oštećenja, čime je potvrđene značajne seizmičke performanse i robustnost HDS koncepta. Ovo je znatno tačnije za viskozni uređaj, kojima se danas daje prednost.

Ključne reči: seizmičko upravljanje, pasivni uređaji za upravljanje, UHYDE-fbr, most sa nosačima i kolovozom na gornjem pojasu, Ispitivanja na vibroplatformi, Hyde Sistem, seizmička robusnost 